\begin{tabular}{|c|c|c|}
\hline & Int.J.Curr.Microbiol.App.Sci (2021) 10(10): 212-220 & \\
\hline & $\begin{array}{l}\text { International Journal of Current Microbiology and Applied Sciences } \\
\text { ISSN: 2319-7706 Volume } 10 \text { Number } \mathbf{1 0}(\mathbf{2 0 2 1 )} \\
\text { Journal homepage: http://www.ijcmas.com }\end{array}$ & 29 \\
\hline $\begin{array}{l}\text { EXCELLENT } \\
\text { PUBLISHERS }\end{array}$ & & \\
\hline
\end{tabular}

Original Research Article

https://doi.org/10.20546/ijcmas.2021.1010.025

\title{
Effects of Irrigation and Nutrient Management on Summer Sesame (Sesamum indicum L.)
}

\author{
P. Chakraborty ${ }^{1}$, M. Das Bairagya ${ }^{1}$, S. Sarkar ${ }^{1}$, J. M. L. Gulati ${ }^{1}$, G. H. Santra ${ }^{2}$, \\ N. Nayak ${ }^{1}$ and B. K. Sahoo ${ }^{1}$ \\ ${ }^{1}$ Department of Agronomy, ${ }^{2}$ Department of Soil science and Agricultural Chemistry, \\ IAS, SOADU, Bhubaneswar, Odisha, India \\ *Corresponding author
}

\begin{tabular}{l} 
K e y w o r d s \\
$\begin{array}{l}\text { Summer sesame, } \\
\text { Irrigation, Nutrient } \\
\text { management, Yield, } \\
\text { Water use } \\
\text { efficiency and } \\
\text { Economics }\end{array}$ \\
\hline Article Info \\
$\begin{array}{l}\text { Accepted: } \\
10 \text { September } 2021 \\
\text { Available Online: } \\
10 \text { October } 2021\end{array}$ \\
\hline
\end{tabular}

\section{A B S T R A C T}

Sesame (Sesamum indicum L.) plays a vital role in the Indian agriculture, industry and export trade. It commonly known as til and also called as "queen of oilseeds" has been known to be one of the earliest domesticated edible oilseeds used by mankind. It is grown in wide range of environments extending from semi-arid tropics and subtropics to temperate regions. A field experiment entitled "effects of irrigation and nutrient management on summer sesame (Sesamum indicum L.)",was conducted at the Agricultural Research Station, Brinjhagiri, Chatabar of Faculty of Agricultural Sciences, Siksha ' $O$ ' Anusandhan (Deemed to be University), Bhubaneswar (Odisha) during summer season of 2021. Treatments included three irrigation levels $\left(\mathrm{I}_{1}: 2\right.$ irrigations at 21 and 63 days after sowing, $\mathrm{I}_{2}$ : 2 irrigations at 21 and 42 days after sowingand $\mathrm{I}_{3}$ : 3 irrigations at 21, 42 and 63 days after sowing) are treated in main plot and four nutrient management $\left(\mathrm{N}_{1}\right.$ : $100 \%$ RDF, $\mathrm{N}_{2}: 100 \% \mathrm{RDF}+2$ t/ha FYM, N $\mathrm{N}_{3}: 100 \% \mathrm{RDF}+2$ t/ha FYM + Jeevamrut @2501/ha and $\mathrm{N}_{4}: 75 \% \mathrm{RDF}+2$ t/ha FYM + Jeevamrut @2501/ha) are treated in sub plot were experimented in split plot design replicate thrice. The experiment was conducted with the variety of TKG- 21 followed the spacing of 30 $\mathrm{cm} \times 10 \mathrm{~cm}$. The experimental soil was sandy loam in texture with the $\mathrm{pH}$ of 5.65 and EC of $7.33 \mathrm{ds} / \mathrm{m}$. The recommended dose of NPK was given $30: 15: 15 \mathrm{~kg} \mathrm{ha}^{-1}$. From the experiment, highest seed yield $\left(643.49 \mathrm{~kg} \mathrm{ha}^{-1}\right)$, haulm yield $(1820.13 \mathrm{~kg}$ $\mathrm{ha}^{-1}$ ) and harvest index (26.04\%) was obtained in $\mathrm{I}_{3} . \mathrm{N}_{4}(75 \% \mathrm{RDF}+2 \mathrm{t} / \mathrm{ha} \mathrm{FYM}$ + Jeevamrut @2501/ha) showed second highest seed yield (652.21 kg ha $\left.{ }^{-1}\right)$, haulm yield $\left(1882.07 \mathrm{~kg} \mathrm{ha}^{-1}\right)$ and harvest index $(25.74 \%)$ which is at per with $\mathrm{N}_{3}$. Highest water use efficiency $\left(2.72 \mathrm{~kg} \mathrm{ha}^{-1} \mathrm{~m}^{-1}\right)$ was calculated in $\mathrm{I}_{2} \mathrm{~N}_{3}$. Hence, it can be conclude that cultivation of sesame under75\% RDF + 2 t/ha FYM + Jeevamrut @2501/ha with 2 irrigations at 21 and 42 days after sowing proved better in terms of yield, economics and water use efficiency. 


\section{Introduction}

Oilseed crops play a vital role in the Indian agriculture, industry and export trade. In India, oilseed crops occupy an area of about 26.53 million hectares with the production of 31.01 million tonnes and average productivity of $1169 \mathrm{~kg} / \mathrm{ha}$ (Anon., 2014). Sesame is cultivated on 15.98 lakh hectares and production of 8.20 lakh tonnes with average productivity of $420 \mathrm{~kg} / \mathrm{ha}$ (Anonymous, 2014). In Odisha, sesame is cultivated in about 51.53 lakh hectares area with an annual production of about 11.45 million tones (Anon., 07). Sesame produces high quality edible oil which is used for cooking and salad. Generally white sesame mixed with jaggery is used to make sweets like ladoos and til, chikkis. Generaly, summer sesame requires 3-4 irrigations on its growing period. Integrated use of organic manure along with chemical fertilizers in sesame helps maintaining stability in crop production as well as improving soil physical and fertility conditions (Deshmukh et al., 2002). Higher seed yield of sesame can be obtained by integrated use of fertilizer along with FYM, vermicompost and Azospirillum (Purushottam, 2005 and Jaishankar and Wahab, 2005). Application of bionutrients (panchgavya and jeevamrut) at branching and flowering stages recorded significantly the highest pod yield $(1482 \mathrm{~kg} / \mathrm{ha})$ as compared to single application either at branching or flowering stage. Uptake of nutrients by the plants was more efficient with the integrated use of inorganic and organic fertilization than that of using all organic sources alone. Beneficial effects of FYM have also been advocated by Mishra (2010) and Maravi (2010). Application of irrigation at branching, flowering and seed development stages increased yield attributing characters and yield of summer sesame (Dutta et al., 2000). Keeping these view in mind, a field experiment entitled "effects of irrigation and nutrient management on summer sesame
(Sesamum indicum L.)", was conducted at the Agricultural Research Station, Brinjhagiri, Chatabar of Faculty of Agricultural Sciences, Siksha 'O' Anusandhan (Deemed to be University), Bhubaneswar (Odisha) during summer sesason of 2021 to evaluate the performance of summer sesame under different irrigation and nutrient management.

\section{Materials and Methods}

The field experiment was carried out at the University Farm of Agricultural Research Station, Brinjhagiri, Chatabar of Faculty of Agricultural Sciences, Siksha O Anusandhan (Deemed to be University), Bhubaneswar (Odisha) during summer sesason of 2021. The location situated in the South east coastal plain Zone of India. The field where the experiments was conducted is located at Latitude is $20.46^{\circ} \mathrm{N}$ and Longitude $85.67^{\circ} \mathrm{E}$. The soil was sandy loam in texture, slidely acidic in reaction ( $\mathrm{pH}$ 5.65), medium in organic carbon $0.30 \%$, with 137.98-20.29$194.16 \mathrm{~kg} \mathrm{ha}^{-1}$ available N-P-K. The experimental sesame 'TKG-21' used in the study is a white seeded variety with duration of 85-95 days was sown at $30 \mathrm{~cm} \times 10 \mathrm{~cm}$ spacing at $1 \mathrm{~cm}$ depth. The experiment was laid out in a split plot design having three levels of irrigation $\left(\mathrm{I}_{1}=2\right.$ irrigations at 21 and 63 days after sowing, $\mathrm{I}_{2}=2$ irrigations at 21 and 42 days after sowing and $\mathrm{I}_{3}=3$ irrigations at 21,42 and 63 days after sowing and four nutrient management $\mathrm{N}_{1}=100 \% \mathrm{RDF}, \mathrm{N}_{2}=$ $100 \% \mathrm{RDF}+2 \mathrm{t} / \mathrm{ha} \mathrm{FYM}, \mathrm{N}_{3}=100 \% \mathrm{RDF}+$ 2 t/ha FYM + Jeevamrut @2501/ha and $\mathrm{N}_{4}=$ $75 \% \mathrm{RDF}+2 \mathrm{t} / \mathrm{ha} \mathrm{FYM}+$ Jeevamrut @ 2501/ha as sub-plot treatments. Sesame was sown on $6^{\text {th }}$ February in the year of 2021. A considerable amount of rainfall $(109.2 \mathrm{~mm})$ occurred during cropping season. A common pre-sowing irrigation was given to all plots and later on irrigation was given as per treatments. The $\mathrm{N}, \mathrm{P}$ and $\mathrm{K}$ were supplied through urea, single super phosphate and 
mutate of potash, respectively. Half of $\mathrm{N}$ along with full dose of $\mathrm{P} \mathrm{kg} / \mathrm{ha}$ and $\mathrm{K}$ were applied as basal and mixed with the soil of the individual plots. The rest of the $\mathrm{N}$ dose (half of recommendation) was top dressed at flowering stage according to the treatment. Crop was harvested at 105 DAS ( $31^{\text {st }}$ May). The biometric data like, plant height $(\mathrm{cm})$, dry matter accumulation $\left(\mathrm{g} \mathrm{m}^{-2}\right)$ and number of branches/plant and yield related data like, number of capsules/plant, test weight $(\mathrm{g})$, seed yield $\left(\mathrm{kg} \mathrm{ha}^{-1}\right)$ and haulm yield $\left(\mathrm{kg} \mathrm{ha}^{-1}\right)$ was taken during maturity period. Harvest index, water use efficiency $\left(\mathrm{kg} \mathrm{ha} \mathrm{mm}^{-1}\right)$ and economics of cultivation were calculated.

\section{Results and Discussion}

\section{Biometric Parameters}

Observations of entire study proved that, at maturity, irrespective of different nutrient management, $I_{3}$ treatment produced tallest plant $(111.3 \mathrm{~cm})$ and shortest plant observed in $\mathrm{I}_{1}$ treatment $(104.4 \mathrm{~cm}) .100 \% \mathrm{RDF}+2 \mathrm{t} / \mathrm{ha}$ FYM + Jeevamrut@ @250 1/ha $\left(\mathrm{N}_{3}\right)$ attained tallest plant height $(110.3 \mathrm{~cm}$ at maturity) followed by $75 \% \mathrm{RDF}+2 \mathrm{t} / \mathrm{ha} \mathrm{FYM}+$ Jeevamrut @250 1/ha (109.0 cm) applied treatment. Whereas, smallest plant height recorded $104.9 \mathrm{~cm}$ on $100 \%$ RDF treatment (table 2). Mondal et al., (1992) concluded that the plant height increased as irrigation frequency and nitrogen fertilizer rates were increased. Sahu et al., (2017) also observed that the plant height found highest in combined application of inorganic and organic fertilizers. There was significant variation of number of branches count per $\mathrm{m}^{2}$ in different irrigation levels are presented in table $2 . \mathrm{I}_{3}$ produced statistically highest number of branches per $\mathrm{m}^{2}$ (4.4) at maturity, where as lowest was founded in $I_{1}$ (3.9). The number of branches is found highest in combined application of inorganic and organic fertilizers was also found by Sahu et al., (2017). Observation revealed that, irrespective of nutrient management, $\mathrm{I}_{3}$ produced highest dry matter $\left(527.55 \mathrm{~g} \mathrm{~m}^{-2}\right)$ followed by $\mathrm{I}_{2}(508.93 \mathrm{~g}$ $\mathrm{m}^{-2}$ ). In different nutrient management, at maturity stage $100 \% \mathrm{RDF}+2 \mathrm{t} / \mathrm{ha} \mathrm{FYM}+$ Jeevamrut@2501/ha $\left(\mathrm{N}_{3}\right)$ produced highest amount of dry matter $\left(540.44 \mathrm{~g} \mathrm{~m}^{-2}\right)$ followed by $\mathrm{N}_{4}\left(513.22 \mathrm{~g} \mathrm{~m}^{-2}\right.$ ) (table 2). Accumulation of dry matter in plants is important in producing a plant capable of high grain yield due to difference of irrigation (De et al., 2002) and different integrated nutrient management (Imayavaramban et al., 2002). Beneficial effects of FYM have also been advocated by Mishra(2010) and Maravi (2010).

\section{Yield and yield attributes}

Highest number of capsules/plant (42.2) counted in $\mathrm{I}_{3}$ treatment. Among different nutrient management, $100 \% \mathrm{RDF}+2 \mathrm{t} / \mathrm{ha}$ FYM + Jeevamrut @2501/ha $\left(\mathrm{N}_{3}\right)$ produced maximum number of capsule/plant (41.4) and number of seeds/capsule (53) represented in table 3 .

These data shows that the number of capsules/plant is found highest in combined application of inorganic and organic fertilizers (Sahu et al., 2017). The significant differences in seed yield due to the different water management treatments (table 3) where the lowest seed yield $\left(597.33 \mathrm{~kg} \mathrm{ha}{ }^{-1}\right)$ were recorded for $I_{1}$. Three irrigations at 21,42 and 63 days after sowing $\left(\mathrm{I}_{3}\right)$ resulted the highest seed yield of $643.49 \mathrm{~kg} \mathrm{ha}^{-1}$ followed by $\mathrm{I}_{2}$ $\left(629.84 \mathrm{~kg} \mathrm{ha}^{-1}\right)$. The maximum amount of seed yield in $\mathrm{I}_{3}$ may be due to producing maximum number of capsule per plant on account of higher availability of water. 
Table.1 Physico-chemical properties of the experimental soil

\begin{tabular}{|c|c|c|c|}
\hline Sl. & Properties & Value & Method used \\
\hline 1. & $\begin{array}{c}\text { Mechanical composition } \\
\text { Sand }(\%) \\
\text { Silt }(\%) \\
\text { Clay }(\%)\end{array}$ & $\begin{array}{c}72.8 \% \\
21.2 \% \\
6 \%\end{array}$ & $\begin{array}{l}\text { International pipette method } \\
\text { (Jackson, 1973) }\end{array}$ \\
\hline 2. & Soil texture & $\begin{array}{c}\text { Sandy } \\
\text { loam soil }\end{array}$ & USDA system (Brady, 1974) \\
\hline 3. & $\mathrm{pH}$ & 5.65 & (Jackson, 1973) \\
\hline 4. & Electrical conductivity $\left(\mathrm{ds} \mathrm{m}^{-1}\right)$ & 7.33 & (Jackson, 1973) \\
\hline 5. & Organic carbon $(\%)$ & 0.30 & $\begin{array}{l}\text { Walkley and Black method (Jackson, } \\
\text { 1973) }\end{array}$ \\
\hline 6. & Available nitrogen $(\mathrm{kg} / \mathrm{ha})$ & 137.98 & $\begin{array}{l}\text { Alkaline permanganate method } \\
\text { (Jackson, 1973) }\end{array}$ \\
\hline 7. & Available phosphorus $(\mathrm{kg} / \mathrm{ha})$ & 20.29 & Olsen's method (Olsen et al., 1954) \\
\hline 8. & Available potassium (kg/ha) & 194.16 & $\begin{array}{l}\text { Flame photometric method (Jackson, } \\
1973 \text { ) }\end{array}$ \\
\hline
\end{tabular}

Table.2 Influence effects of irrigation level and nutrient management on plant height $(\mathrm{cm})$, number of branches/plant, dry matter accumulation $\left(\mathrm{g} \mathrm{m}^{-2}\right)$, number of capsules/plant, test weight $(\mathrm{g})$ of summer sesame

\begin{tabular}{|c|c|c|c|c|c|}
\hline $\begin{array}{l}\text { Treat } \\
\text { ment }\end{array}$ & $\begin{array}{c}\text { Plant } \\
\text { height }(\mathbf{c m})\end{array}$ & $\begin{array}{c}\text { Number of } \\
\text { branches/plant }\end{array}$ & $\begin{array}{c}\text { Dry matter } \\
\text { accumulation }\left(\mathrm{g} \mathrm{m}^{2}{ }^{2}\right)\end{array}$ & $\begin{array}{c}\text { Number of } \\
\text { capsules/plant }\end{array}$ & $\begin{array}{c}\text { Test } \\
\text { weight }(g)\end{array}$ \\
\hline$I_{1}$ & 111.3 & 4.4 & 392.03 & 36.5 & 3.39 \\
\hline $\mathbf{I}_{2}$ & 109.3 & 4.2 & 424.94 & 40.2 & 3.30 \\
\hline $\mathbf{I}_{\mathbf{3}}$ & 111.3 & 4.4 & 430.25 & 42.3 & 3.48 \\
\hline $\begin{array}{c}\text { SEm } \\
( \pm)\end{array}$ & 0.7 & 0.1 & 19.49 & 0.9 & 0.02 \\
\hline $\begin{array}{l}\text { CD } \\
(\mathbf{0 . 0 5})\end{array}$ & 2.8 & 0.4 & 76.53 & 2.8 & 0.05 \\
\hline$N_{1}$ & 109.0 & 4.3 & 423.52 & 40.1 & 3.46 \\
\hline $\mathbf{N}_{2}$ & 104.9 & 3.7 & 391.65 & 37.6 & 3.35 \\
\hline $\mathbf{N}_{3}$ & 107.8 & 4.1 & 414.09 & 39.5 & 3.42 \\
\hline $\mathbf{N}_{4}$ & 110.3 & 4.4 & 433.70 & 41.4 & 3.49 \\
\hline $\begin{array}{c}\text { SEm } \\
( \pm)\end{array}$ & 0.7 & 0.1 & 32.31 & 0.4 & 0.09 \\
\hline $\begin{array}{l}\text { CD } \\
(0.05)\end{array}$ & 2.7 & 0.3 & 126.83 & 1.3 & 0.36 \\
\hline
\end{tabular}


Table.3 Effects of irrigation and nutrient management on seed and haulm yield $\left(\mathrm{kg} \mathrm{ha}^{-1}\right)$, harvest Index $(\%)$ and water use efficiency $\left(\mathrm{kg} \mathrm{ha}^{-1} \mathrm{~mm}^{-1}\right)$ of sesame

\begin{tabular}{|c|c|c|c|c|}
\hline Treatment & $\begin{array}{c}\text { Seed yield } \\
\left(\mathbf{k g ~ h a}^{-\mathbf{1}}\right)\end{array}$ & $\begin{array}{c}\text { Haulm yield } \\
\left(\mathbf{k g ~ h a}^{-\mathbf{1}}\right)\end{array}$ & $\begin{array}{c}\text { Harvest } \\
\text { Index }(\mathbf{\%})\end{array}$ & $\begin{array}{c}\text { Oil } \\
\text { content }(\mathbf{\%})\end{array}$ \\
\hline $\mathbf{I}_{\mathbf{1}}$ & 597.33 & 1775.19 & 25.18 & 46.05 \\
\hline $\mathbf{I}_{\mathbf{2}}$ & 629.84 & 1794.27 & 25.98 & 47.99 \\
\hline $\mathbf{I}_{\mathbf{3}}$ & 643.49 & 1828.13 & 26.04 & 51.44 \\
\hline $\mathbf{S E m}( \pm)$ & $\mathbf{3 . 8 4}$ & $\mathbf{7 . 4 2}$ & $\mathbf{0 . 0 4}$ & $\mathbf{0 . 5}$ \\
\hline $\mathbf{C D}(\mathbf{0 . 0 5})$ & $\mathbf{1 5 . 0 3}$ & $\mathbf{2 9 . 4 5}$ & $\mathbf{0 . 1 5}$ & $\mathbf{2 . 0 4}$ \\
\hline $\mathbf{N}_{\mathbf{1}}$ & 591.94 & 1786.71 & 24.89 & 46.69 \\
\hline $\mathbf{N}_{\mathbf{2}}$ & 617.08 & 1837.85 & 25.14 & 48.01 \\
\hline $\mathbf{N}_{\mathbf{3}}$ & 652.21 & 1882.07 & 25.74 & 50.04 \\
\hline $\mathbf{N}_{\mathbf{4}}$ & 632.99 & 1878.82 & 25.20 & 49.24 \\
\hline $\mathbf{S E m}(\mathbf{\pm})$ & $\mathbf{6 . 1 6}$ & $\mathbf{6 . 4 6}$ & $\mathbf{0 . 1 5}$ & $\mathbf{0 . 8}$ \\
\hline $\mathbf{C D}(\mathbf{0 . 0 5})$ & $\mathbf{2 4 . 6 6}$ & $\mathbf{2 5 . 3 0}$ & $\mathbf{0 . 5 6}$ & $\mathbf{3 . 1}$ \\
\hline & & & & \\
\hline
\end{tabular}

Table.4 Cost of cultivation of summer sesame influenced by irrigation and nutrient management

\begin{tabular}{|c|c|c|c|c|}
\hline Treatments & $\begin{array}{c}\text { Cost of } \\
\text { cultivation (Rs./-) }\end{array}$ & $\begin{array}{c}\text { Gross return } \\
\text { (Rs./-) }\end{array}$ & $\begin{array}{c}\text { Net return } \\
\text { (Rs./-) }\end{array}$ & B:C ratio \\
\hline $\mathbf{I}_{\mathbf{1}} \mathbf{N}_{\mathbf{1}}$ & 26175.00 & 41610.00 & 15435.00 & 1.59 \\
\hline $\mathbf{I}_{\mathbf{1}} \mathbf{N}_{\mathbf{2}}$ & 27575.00 & 42826.00 & 15251.00 & 1.55 \\
\hline $\mathbf{I}_{\mathbf{1}} \mathbf{N}_{\mathbf{3}}$ & 28515.00 & 45667.00 & 17152.00 & 1.60 \\
\hline $\mathbf{I}_{\mathbf{1}} \mathbf{N}_{\mathbf{4}}$ & 27895.00 & 44317.00 & 16422.00 & 1.59 \\
\hline $\mathbf{I}_{\mathbf{2}} \mathbf{N}_{\mathbf{1}}$ & 26175.00 & 43723.00 & 17548.00 & 1.67 \\
\hline $\mathbf{I}_{\mathbf{2}} \mathbf{N}_{\mathbf{2}}$ & 27575.00 & 45853.00 & 18278.00 & 1.66 \\
\hline $\mathbf{I}_{\mathbf{2}} \mathbf{N}_{\mathbf{3}}$ & 28515.00 & 47784.00 & 19269.00 & 1.68 \\
\hline $\mathbf{I}_{\mathbf{2}} \mathbf{N}_{\mathbf{4}}$ & 27895.00 & 46552.00 & 18657.00 & 1.67 \\
\hline $\mathbf{I}_{\mathbf{3}} \mathbf{N}_{\mathbf{1}}$ & 27075.00 & 44301.00 & 17226.00 & 1.64 \\
\hline $\mathbf{I}_{\mathbf{3}} \mathbf{N}_{\mathbf{2}}$ & 28475.00 & 46461.00 & 17986.00 & 1.63 \\
\hline $\mathbf{I}_{\mathbf{3}} \mathbf{N}_{\mathbf{3}}$ & 29415.00 & 49381.00 & 19966.00 & 1.68 \\
\hline $\mathbf{I}_{\mathbf{3}} \mathbf{N}_{\mathbf{4}}$ & 28795.00 & 47754.00 & 18959.00 & 1.66 \\
\hline
\end{tabular}


Fig.1 Meteorological data during cropping season of summer 2021.

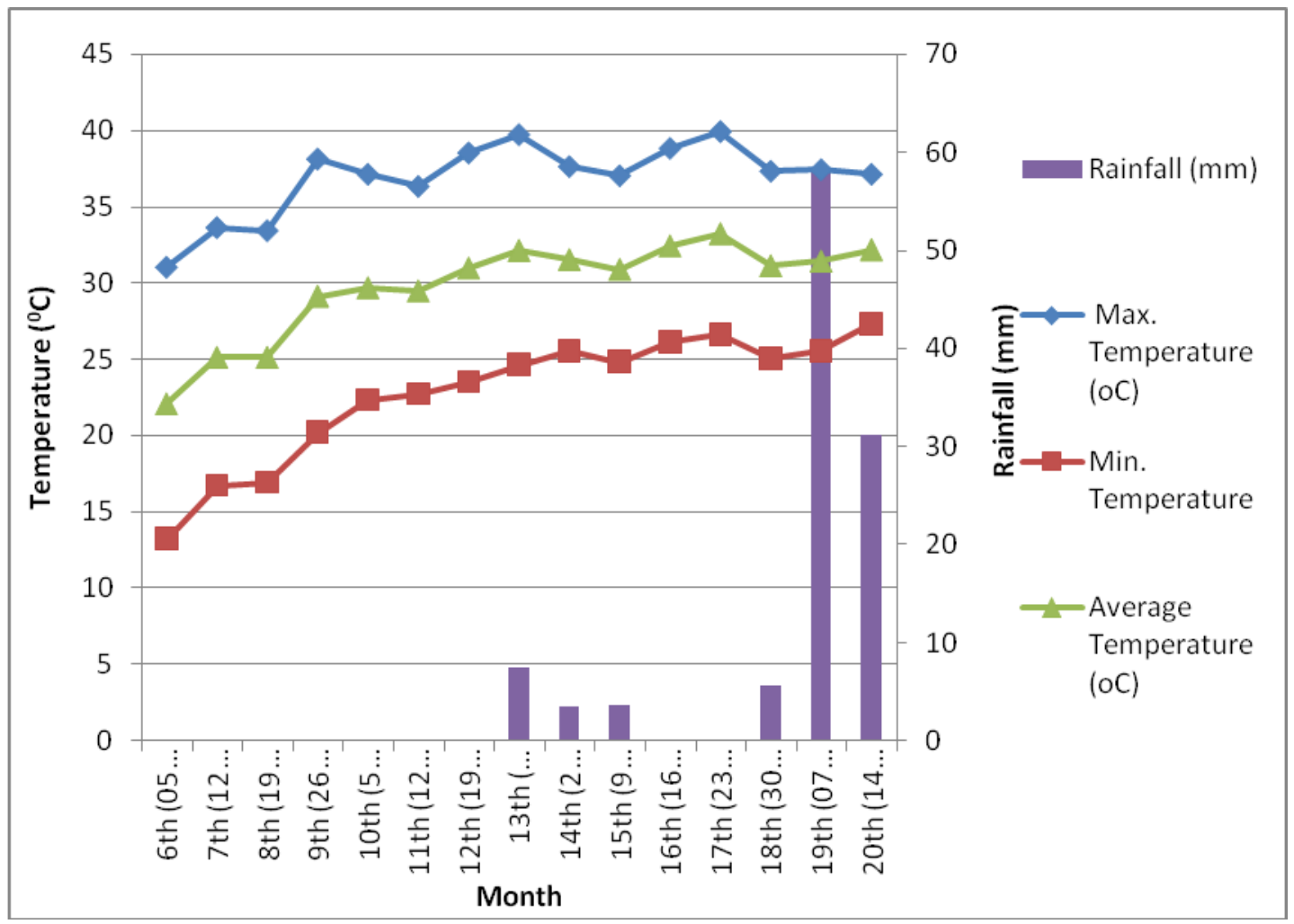

Fig.2 Effects of irrigation and nutrient management on water use efficiency $\left(\mathrm{kg} \mathrm{ha}^{-1} \mathrm{~mm}^{-1}\right)$ of summer sesame.

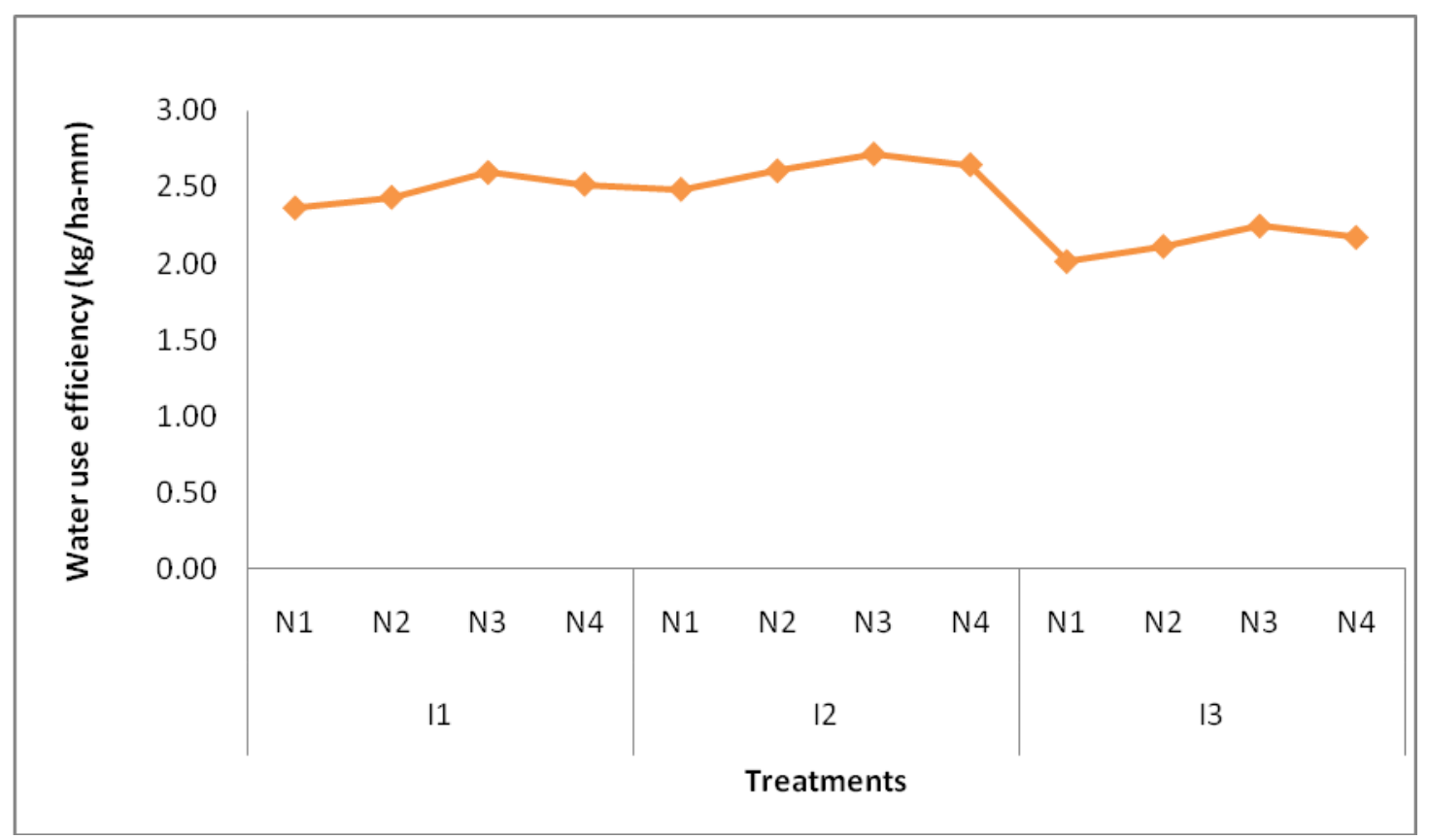


Irrespective of irrigation levels, in different nutrient management, $100 \% \mathrm{RDF}+2 \mathrm{t} / \mathrm{ha}$ FYM + Jeevamrut @2501/ha $\left(\mathrm{N}_{3}\right)$ produced highest yield $\left(652.21 \mathrm{~kg} \mathrm{ha}^{-1}\right)$ followed by $\mathrm{N}_{4}$ $\left(632.99 \mathrm{~kg} \mathrm{ha}^{-1}\right)$ whereas, 100\% RDF $\left(\mathrm{N}_{1}\right)$ gave significantly lowest seed yield (591.94 $\mathrm{kg} \mathrm{ha}^{-1}$ ). From the result it was found that, application of three numbers of irrigations at branching, flowering and seed development stages increased yield attributing characters and yield of summer sesame crop (Dutta et al., 2000).

The higher haulm yield was found in $\mathrm{I}_{3}$ $\left(1828.13 \mathrm{~kg} \mathrm{ha}^{-1}\right)$ followed by $\mathrm{I}_{2}(1794.27 \mathrm{~kg}$ $\left.\mathrm{ha}^{-1}\right)$. The observed data also showed that, haulm yield differs with variation of nutrient management. It is recorded highest in $\mathrm{N}_{3}$ $\left(1882.07 \mathrm{~kg} \mathrm{ha}^{-1}\right)$ followed by $\mathrm{N}_{4}(1878.82 \mathrm{~kg}$ $\left.\mathrm{ha}^{-1}\right)$. Haulm yield preferably increased with integrated nutrient management with fertilizer + FYM + Jeevamrut (Raman and Suganya, 2018). The observation proved that difference nutrient management at different irrigation level i.e., $\left(\mathrm{I}_{3}\right)$ produced highest harvest index $(26.04 \%)$ followed by $\mathrm{I}_{2} \quad(25.98 \%)$. Irrespective of irrigation levels, highest harvest index was calculated in $\mathrm{N}_{3}(25.74 \%)$ followed by $\mathrm{N}_{4}(25.20 \%)$. There is no significant difference among the treatment combination on harvest index. Higher yield obtained in increased irrigation are associated with higher harvest index (Lin et al., 2007).

\section{Oil content}

Three irrigations at 21, 42 and 63 days after sowing resulted the statistically highest oil content of $51.44 \%$ and lowest oil content was found in 2 irrigations at 21 and 63 days after sowing treatment $(46.05 \%)$. Among the different nutrient management, in $100 \% \mathrm{RDF}$ +2 t/ha FYM + Jeevamrut @250 1/ha $\left(\mathrm{N}_{3}\right)$ found the highest oil content $50.04 \%$ (table 3 ). Oil content differences among the irrigation levels may be due to water stress (Boydak et al., 2007). Increased oil content and oil yield may be due to application of more nitrogen (Das and Das, 1995).

\section{Water use efficiency}

The results revealed significant difference in seed yield due to the different water management treatments (figure 4.1). The lowest WUE was recorded for $\mathrm{I}_{3} \mathrm{~N}_{1}(2.02 \mathrm{~kg}$ $\left.\mathrm{ha}^{-1} \mathrm{~mm}^{-1}\right)$. It is due to there was not much yield increment with the increase application of water in $\mathrm{I}_{3}$. Treatment $\mathrm{I}_{2} \mathrm{~N}_{3}$ produced highest WUE of $2.72 \mathrm{~kg} \mathrm{ha}^{-1} \mathrm{~mm}^{-1}$ followed by $\mathrm{I}_{2} \mathrm{~N}_{4}\left(2.65 \mathrm{~kg} \mathrm{ha}^{-1} \mathrm{~mm}^{-1}\right)$. Present research showed that the practice of limiting water applications to drought-sensitive growth stages aims at maximizing water productivity and stabilizing, rather than maximizing, yields which is supported by S. Geerts and D. Raes, (2009). The WUE increases with irrigation amount and water-saving techniques such as deficit level have been improved water use efficiency (WUE) with minimum yield reduction which was earlier reported by Ucan, 2007.

\section{Cost of cultivation}

The cost of cultivation, gross return, net return and benefit:cost ratio are presented in Table 4. Highest net return (Rs.19966.00/-) as well as benefit cost ratio (1.68) calculated in $\left(\mathrm{I}_{3} \mathrm{~N}_{3}\right)$. Though the treatment $\mathrm{I}_{2} \mathrm{~N}_{3}$ found same benefit cost ratio (1.68) but the second highest net return (Rs.19269.00 /-) obtained from this treatment. The lowest net return (Rs.15251.00/-) as well as benefit cost ratio (1.55) calculated in treatment $\mathrm{I}_{1} \mathrm{~N}_{2}$.

The application of 2 irrigations at 21 and 42 days after sowing produced significantly higher yield (629.84 $\mathrm{kg} \mathrm{ha}^{-1}$ ) compared to highest in 3 irrigations at 21, 42 and 63 days after sowing $\left(643.49 \mathrm{~kg} \mathrm{ha}^{-1}\right)$. It is further infrared that the summer sesame recorded 
significantly higher seed yield (676.5 kg ha $\left.{ }^{-1}\right)$, net return (Rs. 19966.00/- /ha) and benefit : cost ratio (1.68) in 3 irrigations at 21, 42 and 63 days after sowing with 100\% RDF, 2 t/ha FYM and Jeevamrut @250 1/ha application. However, the highest water use efficiency calculated $\left(2.72 \mathrm{~kg} \mathrm{ha}^{-1} \mathrm{~mm}^{-1}\right)$ in 2 irrigations at 21 and 42 days after sowing with $100 \%$ RDF, 2 t/ha FYM and Jeevamrut@250 1/ha application.

\section{Acknowledgement}

The authors are very much thankful to Department of Agronomy, IAS, SOADU, for providing financial and laboratory equipments for present study.

\section{References}

Anonymous. 2007. Economic Intelligence Service (Centre for Monitoring Indian Economy).

Anonymous. 2014. Status Paper on Oilseeds, Oilseeds Division, Department of Agriculture and Cooperation Ministry of Agriculture, Govt. of India.

Boydak, E., Karaaslan, D., Simsek, M., Gercek, S., Kirnak, H., Kasap, Y and Ozturk, I. 2007. Effects of irrigation methods and irrigation intervals on yield and some yield components of sesame growing in semi-arid area. Journal of Agronomy. 6(3): 439-443.

Das, K. N and Das, K. 1995. Effect of sulphur and nitrogen fertilizer on growth and yield of toria (Brassica campestris sub sp. oleifera var. toria). Indian Journal of Agronomy. 40: 329-331.

De, P., Majumdar, D. K and De, G. C. 2002. Studies on the effect of irrigation and intercropping of summer sesame and mung in the lateritic belt of West Bengal. Journal of Interacad., 6: 27279.

Deshmukh, M. R., Jain, H. C., Duhoon, S. S and Goswami, U. 2002. Integrated nutrient management in sesame (Sesamum indicum L.) for Kymore plateau zone of Madhya Pradesh. Journal of Oilseeds Research. 19(1):73-75.

Dutta, D., Jana, P. K., Bandyopadhyay, P. and Maity, D. 2000. Response of summer sesame (Sesamum indicum L.) to irrigation. Indian Journal of Agronomy. 45(3): 613-616.

Geerts, S and Raes, D. 2009. "Deficit irrigation as an on-farm strategy to maximize crop water productivity in dry areas". Agricultural water management. 96(9):1275-1284,.

Imayavaramban, V., Thanunathan, K., Singaravel, R and Manickam, G. 2002. Studies on the influence of integrated nutrient management on growth, yield parameters and seed yield of sesame (Sesamum indicum L.). Crop Research. 24(2): 309-313.

Jaishankar, S and Wahab, K. 2005. Effect of integrated nutrient management on the growth, yield components and yield of sesame. Sesame and Safflower Newsletter. 20: 732.

Lin, L., Xu, B.C and Li, F. M. 2007. Effects of limited irrigation on yield and water use efficiency of two sequence placed winter wheat. African Journal of Biotechnology. 6 (13): 1493-1497.

Maravi, Preeti., 2010. Development of organic nutrient management for sesame (Sesamum indicum L.). M.Sc. (Ag.)Thesis (Unpublished), JNKVV, Jabalpur. 84.

Mishra, P. 2010. Effect of nutrient management on growth and yield of sesame (Sesamum indicum L.). M.Sc.(Ag.)Thesis (Unpublished) JNKVV, Jabalpur. 76.

Mondal, S. S., Verma, D and Kulia, S. 1992. Effect of organic and inorganic sources of nutrients on growth and seed yield 
of sesame (Sesamum indicum L.). Indian Journal of Agricultural Science. 62(4):258-262.

Purushottam, G. 2005. Integrated nutrient management in sesame (Sesamum indicum L.) and its residual effect on succeeding chickpea (Cicer arietinum L.). M.Sc.(Ag.) in Agronomy Thesis submitted to the University of Agricultural Sciences, Dharwad, Karnataka.

Raman, R and Suganya, K. 2018. Effects of integrated nutrient management on the growth and yield of hybrid rice. Journal of Agricultural Research. 3(2):
156-159.

Sahu, G., Chatterjee, N., Bera, M., Ghosh, G. K., Mondal, S., Biwas, P. K and Kundu, M. C. 2017. Integrated nutrient management in sesame (Sesamum indicum L.) in red and lateritic soils of west Bengal. Internatioal journal of plant, animal and environmental sciences. 7(1): 137-146

Uçan, K., Kıllı, F., Genço ־glan, C., Merdun, H. 2007. Effect of irrigation frequency and amount on water use efficiency and yield of sesame (Sesamum indicum L.) under field conditions. Field Crop. Research. 101: 249-258.

\section{How to cite this article:}

Chakraborty, P., M. Das Bairagya, S. Sarkar, J. M. L. Gulati, G. H. Santra, N. Nayak and Sahoo, B. K. 2021. Effects of Irrigation and Nutrient Management on Summer Sesame (Sesamum indicum L.). Int.J.Curr.Microbiol.App.Sci. 10(10): 212-220.

doi: https://doi.org/10.20546/ijcmas.2021.1010.025 